Environment, Biodiversity \& Soil Security
(EBSS)
http://jenvbs.journals.ekb.eg//

\title{
Can Humic Acid Alleviate The Adverse Effect of Elevated Phosphorus Application on Yield and Nutritive Contents of Maize Grown on a Calcareous Soil?
}

\author{
Mohamed F. Abd El- Aziz' ${ }^{1}$, Mohamed H. H. Abbas ${ }^{2 *}$ and Ashraf M. G. Ewis ${ }^{3}$ \\ ${ }^{1}$ Soils, Water and Environment Research Institute (SWERI), Agric. Research Centre \\ (ARC), Giza, Egypt \\ ${ }^{2}$ Department of Soils and Water, Faculty of Agriculture, Benha University, Egypt \\ ${ }^{3}$ Department of Soils and Water, Faculty of Technology and Development, Zagazig \\ University, Egypt
}

\begin{abstract}
ROWING maize in calcareous soils requires adequate supply of phosphorus inputs, Jet excessive P-applications may affect negatively micronutrients availability in soil, including $\mathrm{Zn}$. Thus, the current study evaluates the ability of humic acid (HA) to counteract the negative effects of applied $\mathrm{P}$ on $\mathrm{Zn}$-uptake by maize plants. To achieve this aim, a field experiment was conducted in a calcareous soil $\left(\mathrm{CaCO}_{3}=268.91 \mathrm{~g} \mathrm{~kg}^{-1}\right)$ following a split plot design to study the interactions between different P-inputs (100, 125 and 150\% of the recommended dose, applied in main plots) and available- $\mathrm{Zn}$ in presence and absence of HA (applied in sub-plots at either 2 or $4 \mathrm{~kg} \mathrm{HA} \mathrm{ha}^{-1}$ ). Results revealed that increasing the level of $\mathrm{P}$-application raised significantly $\mathrm{P}$ availability and consequently its uptake by maize plants; thus, enhanced significantly plant growth parameters and grain yield. In this concern, $125 \%$ of the recommended P-dose recorded the highest partial factor productivity values. Likewise, application of HA raised significantly available-P content and improved considerably plant growth and grain yield, especially with increasing the rate of its application. On the other hand, increasing the level of P-fertilizers decreased significantly $\mathrm{Zn}$-availability and uptake by plants; however, in presence of HA, this effect was counteracted. Although, this amendment recorded no significant effect on soil-Zn availability; however, it raised significantly its content in shoots but not in grains. In conclusion, HA improved significantly the productivity of maize grown on a calcareous soil. This amendment not only improved the partial factor productivity of P-fertilizer, but also increased Zn-uptake by maize plants.
\end{abstract}

Keywords: Calcareous soil; Nutrient availability; Plant uptake; Humic acid; P-Zn interactions; Partial factor productivity.

\section{Introduction}

Calcium carbonate precipitates, the major constituents in arid and semi-arid soils (Virto et al. 2018), exist mainly in micritic or microsparitic crystals (Durand et al. 2018). In Egypt, calcareous soils are wide spread in many regions of the Northern coast of the Mediterranean Sea (Morsy et al. 2019), Abu El-Matamir, El-Beheira Governorate (Abou Hussien et al. 2019), ElNubaria region (Abdelhameid, 2020), North Sinai and Fayoum (Attia, 2019). These soils are characterized by their low available micro-nutrient contents (Karimi et al. 2020). Thus, plants grown thereon exhibit the symptoms of micronutrient deficiency unless using untraditional approaches to satisfy plant needs for nutrients such as using nano-fertilizers (Abdalla et al. 2018; El-Ghamry et al. 2018; Cieschi et al. 2019; Omara et al. 2019) and synthetic chelates (Wang et al. 2017; Rajaie and Tavakoly, 2018; López-Rayo et al. 2019). It is worthy to mention that these nano-materials may pose potential health threats when enters food chain (Zulfiqar et al. 2019). Also, synthetic

"Corresponding author e-mail: mohamed.abbas@fagr.bu.edu.eg

Received: 29/10/2020; Accepted: 16/11/2020

DOI: $10.21608 /$ jenvbs.2020.48032.1112

C2020 National Information and Documentation Center (NIDOC) 
chelates degrade comparatively slow (Freitas and Nascimento, 2017). Thus, there is an actual need to use safe ecofriendly methods to improve nutrient availability in such calcareous soils.

Maize is an important protein and calorie source for millions of people across developing countries (Saritha et al. 2020). It is also used in many food and industrial products, e.g. starch, sweeteners, oil, beverages, glue, industrial alcohol, and fuel ethanol (Ranum et al. 2014). Growing maize plants in calcareous soils requires adequate supply of phosphorus inputs (Leytem et al. 2011), yet excessive $\mathrm{P}$ applications may affect negatively micronutrient availability in such soils (Sims and Pierzynski, 2005), including Zn (Wang et al. 2019), consequently lessen their uptake by plants (Zhang et al. 2012). Another negative aspect of using P-fertilizers in calcareous soils is that these soluble P-fertilizers are of low use efficiency because P-inputs undergo rapid immobilization (Bindraban et al. 2020) through adsorption on the calcite surface (Izhar Shafi et al. 2020). Thus, proper management of nutritive inputs is required to sustain crop productivity grown on such soils. These nutrients not only represent a crucial issue in growing crop plants (El-Ramady et al. 2020) but also very important to meet the standards of food and fodder consumption (Vagerial et al. 2008).

One of the promising approaches to increase both $\mathrm{P}$ and micronutrient availability in soils is through amending soils with humic acid (HA) (Farid et al. 2018). This organic amendment may set $\mathrm{P}$ free in soil; hence, increase its uptake by plants (IzharShafi et al. 2020). Moreover, it may effectively increase micro-nutrient availability in soils (Olmos et al. 1998; Maruf and Rasul, 2019) probably through formation of soluble complexes (Dhaliwal et al. 2019; Boguta and Sokolowska, 2020). In case of $\mathrm{Zn}$, HA probably reduces its bioavailability (Rong et al., 2020); in spite of that this organic amendment has positive impacts on $\mathrm{Zn}$ uptake (Horuz, 2020). It is worthy to mention that HA applications may have negative impacts on maize growth under calcareous conditions if amended at a rate of $2 \mathrm{~g} \mathrm{HA} \mathrm{kg}^{-1}$ (equivalent to $4.8 \mathrm{~kg} \mathrm{HA} \mathrm{ha}^{-1}$ ) or higher (Leventoglu and Erdal, 2014). Such a finding requires further investigations on calcareous soils differing in both size and contents of $\mathrm{CaCO}_{3}$ to maximize crop productivity grown thereon.

The current study evaluates the ability of HA to increase the productivity of maize plants grown on a calcareous soil though increasing further inputs of P-fertilizer (added as calcium superphosphate) in these soils as a necessary protocol to compensate the $\mathrm{P}$ fixed amounts. However, it is expected that the excessive applied $\mathrm{P}$ would negatively affect availability of some micro-nutritve elements e.g., $\mathrm{Zn}$ and consequently decrease their uptake by plant. Therefore, the current investigation involves also the application of HA which is thought to counteract the effect of the applied $\mathrm{P}$ and enhance the uptake of $\mathrm{Zn}$ by plant. Moreover, the interactions between P-inputs and soil-Zn in presence and absence of HA will be taken into account.

\section{Materials and Methods}

Materials of study

The current study was conducted in a private farm in El-Noubaria area, North West region of Egypt (3046' 18.7" N 29०39'39.3" E). This location is characterized by a short rainy season and a long hot summer one with high relative humidity (Alnaimy et al. 2018). Prior to the experimental study, a surface soil sample (0-30 $\mathrm{cm}$ ) was collected from the experimental field, air dried, ground and sieved to pass through a $2 \mathrm{~mm}$ sieve. Afterwards, this sample was investigated for its physical and chemical properties as outlined by Klute (1986) and Sparks et al. (1996), respectively. The obtained results are presented in Table 1.

Humic acid (analytical grade, 99\%) was obtained from Alpha Chemika Company, India. Seeds of maize (Zea mays L.cv. Hybrid 310) were obtained from the Agriculture Research Centre, Giza.

TABLE 1. Some physical and chemical properties of the field soil

\begin{tabular}{ll}
\hline Parameter & value \\
\hline Coarse sand & 12.48 \\
Fine sand & 43.66 \\
Silt & 19.27 \\
Clay & 24.59 \\
Soil texture (USDA) & Sandy clay \\
& loam \\
Bulk density, $\mathbf{M g ~ m}^{-3}$ & 1.41 \\
pH & 7.80 \\
Organic matter content, $\mathbf{g ~ k g}^{-1}$ & 6.43 \\
Total CaCO, , kg $^{-1}$ & 268.91 \\
SAR & 7.82 \\
AB-DTPA extractable $\mathbf{P}, \mathbf{~ m g ~ k g}^{-1}$ & 10.9 \\
AB-DTPA extractable $\mathbf{~ Z n , ~} \mathbf{~ m g ~ k g}^{-1}$ & 0.87 \\
\hline
\end{tabular}




\section{The experimental study}

A field experiment was conducted at a private field of a calcareous nature in El Noubaria region following a split-plot design (the experimental plot was $3.5 \times 3.0 \mathrm{~m}^{2}$ ) with three replicates for each treatment. The different application rates of P-fertilizer (calcium super phosphate, $65.5 \mathrm{~g} \mathrm{P}$ $\mathrm{kg}^{-1}$ ) i.e., $30 \mathrm{~kg} \mathrm{P}$ (the recommended dose), $38 \mathrm{~kg}$ $\mathrm{P}(125 \%$ of the recommended dose) and $45 \mathrm{kgP}$ $\mathrm{ha}^{-1}(150 \%$ the recommended dose $)$ were located at the main plots, while humic acid treatments $\left(0,2\right.$ and $\left.4 \mathrm{~kg} \mathrm{ha}^{-1}\right)$ were placed in sub-plots. Seeds of maize were then planted at the second half of April (2019) and all plots received NK rates as recommended by the Egyptian Ministry of Agriculture i.e., $350 \mathrm{~kg} \mathrm{~N}^{-1}$ as urea $(46.5 \%$ $\mathrm{N})$ and $47 \mathrm{~kg} \mathrm{~K} \mathrm{ha}^{-1}$ as potassium sulfate $(48 \% \mathrm{~K})$.

Common agricultural practices were followed as recommended according to the local conditions. At physiological maturity growth stage (110 days after planting), the above ground plant parts were harvested; plant growth parameters (plant height and straw biomass) as well as the gain yield and 100-seed weight were then estimated. Also, surface soil samples were collected from the rhizosphere of each treatment during plant harvest to determine the available contents of $\mathrm{P}$ and $\mathrm{Zn}$ in these samples.

\section{Soil and plant analyses}

Plant materials were oven dried at $70^{\circ} \mathrm{C}$ for $48 \mathrm{hr}$, then acid digested using a tri-acid mixture $\left(\mathrm{HNO}_{3}: \mathrm{H}_{2} \mathrm{SO}_{4}: \mathrm{HClO}_{4}, 10: 4: 1\right)$ according to Sahrawat et al. (2002). The available forms of $\mathrm{P}$ and $\mathrm{Zn}$ in soil samples were extracted by ammonium bicarbonatediethylene triaminepenta acetic acid (AB-DTPA) according to Soltanpour (1985). Total P and Zn were then estimated in both plant digests and soil extracts using ICP-MS (model ULTIMA 2).

\section{Data Analyses}

Data were statistically analyzed using PASW statistical software 18 through the analysis of variance (ANOVA) and Dunken's test at 0.05 probability level. Graphs were plotted using SigmaPlot 10 software. Phosphorus-partial factor productivity (P-PFP) was estimated according to Cassman et al. (1998) and Yadav et al. (2000) as follows:

Phosphorus-partial factor (P-PFP) $=$ seed yield (kg ha-1)/ amount of applied P-fertilizer (kg ha1)

\section{Results and Discussion}

Plant height and yield components of maize plants

The investigated growth parameters i.e., plant height and straw biomass as well as the grain yield increased significantly owing to increasing the level of P-application (Table 2). This is because this nutrient directly and indirectly affects plant biological processes (Raghothama, 2005; Shams and Abbas, 2019). It seems that increasing the level of P from 38 to $45 \mathrm{~kg} \mathrm{P} \mathrm{ha}^{-1}$ had no further significant effect on either plant height or straw biomass; however, such increases resulted in significant increases in grain yield. Thus, it can be deduced that $\mathrm{P}$ applications probably motivated maize plants grown on calcareous soils towards flowering development, rather than increasing vegetative growth. Phosphorus is considered an essential nutrient for energy-related processes in plants (Elserand Bennett, 2011) which are responsible for starch synthesis and transportation into the storage cells (Engels et al. 2012).

Application of HA also enhanced significantly the investigated plant growth parameters and grain yield, especially with increasing its rate of application, except for 100seed weight where no significant variations were detected among treatments. This might occur because HA increased significantly nutrients availability (El-Negma, 2020) and uptake by the grown plants through forming soluble organometal complexes (Baigorriet al. 2019). Yet the effects of P-applications on plant yield seemed to be higher than the corresponding ones of HA. Further investigations on the implications of both P-application dose and HA on P and $\mathrm{Zn}$ availability and uptake would be discussed below.

Interactions among the applied doses of P-fertilizer and HA were also of significant effect (Fig. 1). In this concern, the highest increases in the investigated parameters were attained for plants that received $150 \%$ of the recommended dose of P i.e. $45 \mathrm{~kg} \mathrm{P}+4 \mathrm{~kg}$ $\mathrm{HAha}^{-1}$. Such increases were about 1.9 and 1.7 folds higher than the reference treatment (the recommended dose of $\mathrm{P}+0 \mathrm{~kg} \mathrm{HAha}^{-1}$ ) in straw and grain yields, respectively. These results agree with those of Delgado et al. (2002), who revealed that HA applications increased the efficiency of P fertilizers. 
TABLE 2. Grand means of maize height, straw and grain yields and the weight of 100 grain as affected by the applied $P$ and humic acid

\begin{tabular}{|c|c|c|c|c|}
\hline Rate of application & Plant height, $\mathrm{cm}$ & Straw biomass, Mg ha $^{-1}$ & $\begin{array}{c}\text { Grain yield, } \\
\mathrm{Mg} \mathrm{ha}^{-1}\end{array}$ & $\begin{array}{l}\text { Weight of } \\
\text { 100-grain }\end{array}$ \\
\hline \multicolumn{5}{|c|}{ P-dose } \\
\hline 30.0 kg P ha ${ }^{-1}$ & $180.33 b$ & $4.04 \mathrm{~b}$ & $2.65 \mathrm{c}$ & $28.65 \mathrm{a}$ \\
\hline 37.5 kg P ha $^{-1}$ & $194.67 \mathrm{a}$ & $6.90 \mathrm{a}$ & $3.17 \mathrm{~b}$ & $29.88 \mathrm{a}$ \\
\hline $45.0 \mathrm{~kg} \mathrm{P} \mathrm{ha-1}$ & $197.67 \mathrm{a}$ & $6.79 \mathrm{a}$ & $3.53 \mathrm{a}$ & $29.74 \mathrm{a}$ \\
\hline$P$-value & $8.554^{* *}$ & $4.983^{*}$ & $19.979 * *$ & 0.569 \\
\hline \multicolumn{5}{|c|}{ Humic acid dose } \\
\hline 0 kg HAha ${ }^{-1}$ & $179.33 \mathrm{c}$ & $5.47 \mathrm{~b}$ & $2.67 \mathrm{c}$ & $29.28 \mathrm{a}$ \\
\hline 2 kg HA ha ${ }^{-1}$ & $190.67 \mathrm{~b}$ & $5.96 \mathrm{ab}$ & $3.15 \mathrm{~b}$ & $29.46 \mathrm{a}$ \\
\hline 4 kg HA ha ${ }^{-1}$ & $202.67 \mathrm{a}$ & $6.29 \mathrm{a}$ & $3.53 \mathrm{a}$ & $29.53 \mathrm{a}$ \\
\hline$P$-value & $13.572 * *$ & $76.852 * *$ & $18.963 * *$ & 0.979 \\
\hline
\end{tabular}

* Significant at 0.05

** significant at 0.01
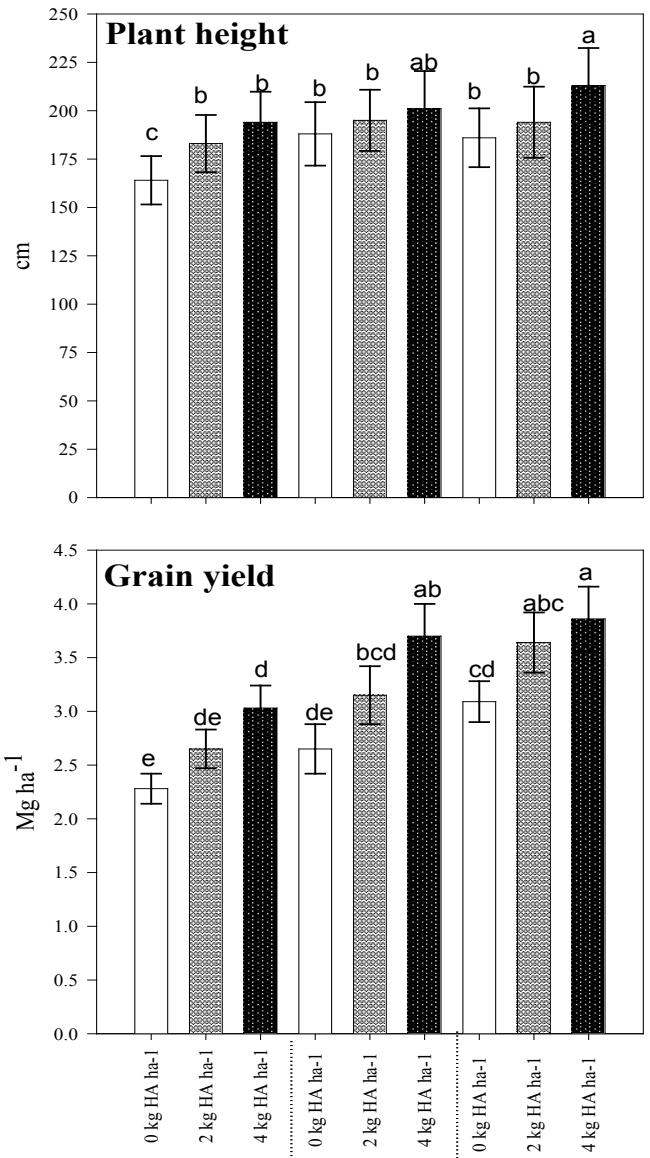

$$
30 \mathrm{~kg} \mathrm{P} \mathrm{ha-1}\left|38 \mathrm{~kg} \mathrm{Pha}^{-1}\right| 45 \mathrm{~kg} \mathrm{P} \mathrm{ha}^{-1}
$$
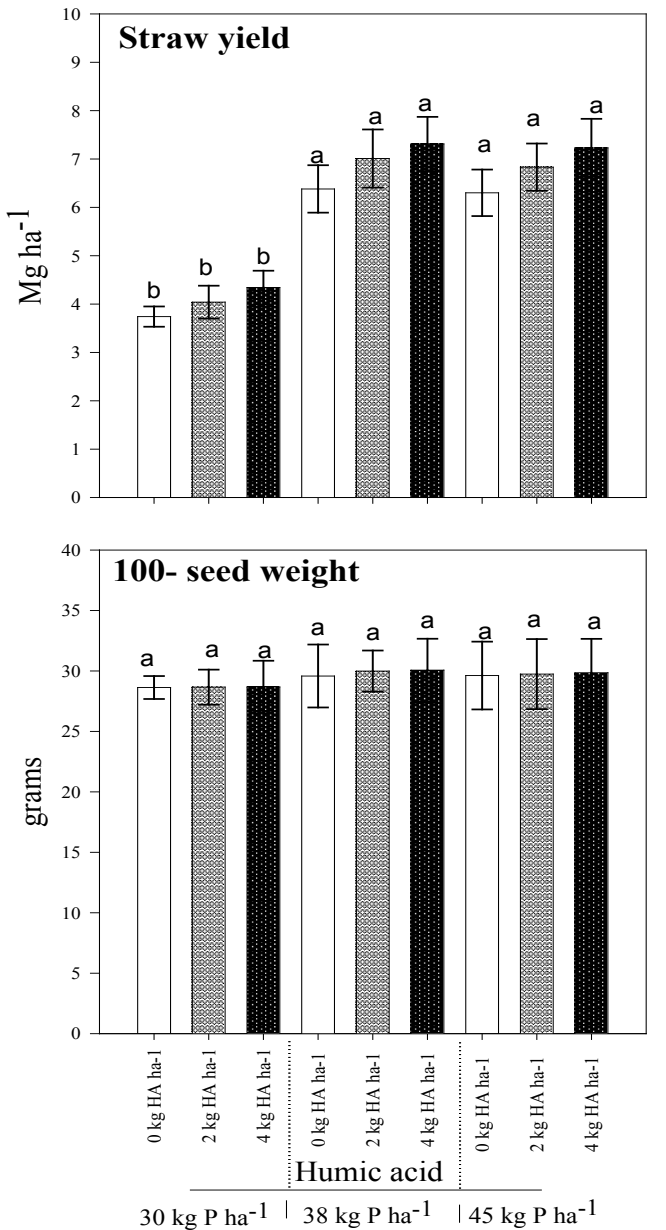

Fig.1. Plant height, straw and grain yield as well as 100-seed weight of maize plants grown on a calcareous soil as affected by applied $P$ and humic acid. P-treatments were $30 \mathrm{~kg} P$ (the recommended dose), $38 \mathrm{~kg} P$ (125\% of the recommended dose) and $45 \mathrm{~kg} P$ (150\% the recommended dose) $\mathrm{ha}^{-1}$ while humic acid treatments were 0,2 and $4 \mathrm{~kg} \mathrm{ha}^{-1}$. Different letters indicate significant variations among treatments

Env. Biodiv. Soil Security Vol. 4 (2020) 
Concentrations of $P$ and $Z n$ in shoots and grains of maize

Table 3 reveals that increasing the dose of applied $\mathrm{P}$ (higher than the recommended dose i.e. 38 and $45 \mathrm{~kg} \mathrm{P}$ ha $^{-1}$ ) raised significantly P-contents in both shoots and grains. In this concern, no significant variations were detected in P-contents within the studied plant parts among those received whether 38 or $45 \mathrm{~kg} \mathrm{P} \mathrm{ha}^{-1}$. On the other hand, increasing the dose of $\mathrm{P}$-application decreased significantly $\mathrm{Zn}$ contents in both shoots and grains. This might occur because of $\mathrm{Zn}$ precipitation in soil in the form of zinc phosphate (Wang et al. 2019). In presence of humic acid, significant increases occurred in concentrations of $\mathrm{Zn}$ in shoots and grains, especially in presence of the highest application level of humic acid (4 kg $\mathrm{ha}^{-1}$ ). Likewise, humic acid raised significantly $\mathrm{Zn}$ contents in shoots but not in grains. Generally, Zn is an essential nutrient for proper plant growth and reproduction (Noulas et al. 2018) that stimulates the antioxidant enzymes for counteracting drought effects (Umair Hassan et al. 2020). It also plays important roles in plant defense mechanisms against pathogens (Cabot et al. 2019). It is worthy to mention that increasing the dose of P-fertilizers decreased significantly $\mathrm{Zn}$ content within spring wheat shoots (Zhu et al. 2001). Our results did not support such findings in maize plants that were treated with humic acid where this amendment improved significantly $\mathrm{P}$ and $\mathrm{Zn}$ contents within both shoots and grains. Probably, P-fertilizers stimulated the growth of plant roots (Gao et al. 2019) and consequently improved Zn uptake by plants (Nikbakht et al. 2008). Our findings did not also contradict those of Jones et al. (2007) who reported that application of humic acid did not affect significantly micronutrient uptake, as the authors used a low-grade commercial HA in their experimental study.

Interactions among P-treatments and humic acid were also of significant effects on both $P$ and $\mathrm{Zn}$ contents in shoots and grains, except for $\mathrm{Zn}$ content in grains. Generally, the highest records were detected in plants that received $45 \mathrm{~kg} \mathrm{P}+4$ $\mathrm{kg} \mathrm{HA} \mathrm{ha}{ }^{-1}$ (Fig 2). Although, HA raised Zn contents in shoot while this content decreased with increasing the dose of P-fertilizers. These two factors were of no significant effect on $\mathrm{Zn}$ content in maize grains, probably insignificant variations were due to dilution of $\mathrm{Zn}$ within grains that increased in yield with $\mathrm{P}$ fertilization as outlined by Hawkesford et al. (2012).

\section{Availability of $P$ and $\mathrm{Zn}$ in soil}

Increasing the dose of applied P-fertilizer increased significantly the availability of $\mathrm{P}$ (AB-DTPA-P) in soil (Table 4). On the other hand, P-applications reduced significantly $\mathrm{Zn}$ availability (AB-DTPA-Zn) in soil (Fig 3). This might be attributed to the precipitation of $\mathrm{Zn}$ in soil in the form of $\mathrm{Zn}_{3}\left(\mathrm{PO}_{4}\right)_{2}$ as shown below:

$$
\begin{aligned}
& 3 \mathrm{Zn}^{2+}+2 \mathrm{H}_{2} \mathrm{PO}_{4}^{-}+4 \mathrm{H}_{2} \mathrm{O} \leftrightarrows \mathrm{Zn}_{3}\left(\mathrm{PO}_{4}\right)_{2} \cdot 4 \mathrm{H}_{2} \mathrm{O} \\
& \text { (hopeite) }+4 \mathrm{H}^{+} \quad \text { (Lindsay, 1979) }
\end{aligned}
$$

The produced hydrogen ions were then neutralized by the $\mathrm{OH}^{-}$ions under the alkaline conditions of the calcareous soil; hence shifting the reaction towards further $\mathrm{Zn}_{3}\left(\mathrm{PO}_{4}\right)_{2} \cdot 4 \mathrm{H}_{2} \mathrm{O}$ precipitations.

TABLE 3. Grand means of $P$ and $\mathrm{Zn}$ contents in shoots and grains of maize plants grown on a calcareous soil as

\begin{tabular}{|c|c|c|c|c|}
\hline \multirow[t]{2}{*}{ Rate of application } & \multicolumn{2}{|c|}{ P content, $\mathrm{g} \mathrm{kg}^{-1}$} & \multicolumn{2}{|c|}{ Zn content, $\mathrm{mg} \mathrm{kg}^{-1}$} \\
\hline & Shoot & Grain & Shoot & Grain \\
\hline \multicolumn{5}{|c|}{ P-dose } \\
\hline 30.0 kg P ha ${ }^{-1}$ & $3.82 b$ & $2.38 \mathrm{~b}$ & $25.22 \mathrm{~b}$ & $7.75 \mathrm{~b}$ \\
\hline $37.5 \mathrm{~kg} \mathrm{P} \mathrm{ha}^{-1}$ & $4.42 \mathrm{a}$ & $2.56 \mathrm{a}$ & $22.32 \mathrm{~b}$ & $7.65 \mathrm{~b}$ \\
\hline 45.0 kg $P$ ha $^{-1}$ & $4.69 \mathrm{a}$ & $2.60 \mathrm{a}$ & $20.81 \mathrm{a}$ & $7.57 \mathrm{a}$ \\
\hline$P$-value & $7.619 * *$ & $5.337 *$ & $8.98 * *$ & 0.146 \\
\hline \multicolumn{5}{|c|}{ Humic acid dose } \\
\hline 0 kg HA ha ${ }^{-1}$ & $3.80 \mathrm{~b}$ & $2.39 \mathrm{~b}$ & $21.06 \mathrm{~b}$ & $7.59 \mathrm{a}$ \\
\hline 2 kg HA ha- & $4.52 \mathrm{a}$ & $2.56 \mathrm{a}$ & $22.08 \mathrm{~b}$ & $7.62 \mathrm{a}$ \\
\hline 4 kg HA ha ${ }^{-1}$ & $4.60 \mathrm{a}$ & $2.59 \mathrm{a}$ & $25.21 \mathrm{a}$ & $7.76 \mathrm{a}$ \\
\hline$P$-value & $7.347 * *$ & $5.284 *$ & $8.34 * *$ & 0.165 \\
\hline
\end{tabular}
affected by the applied $P$ and humic acid 


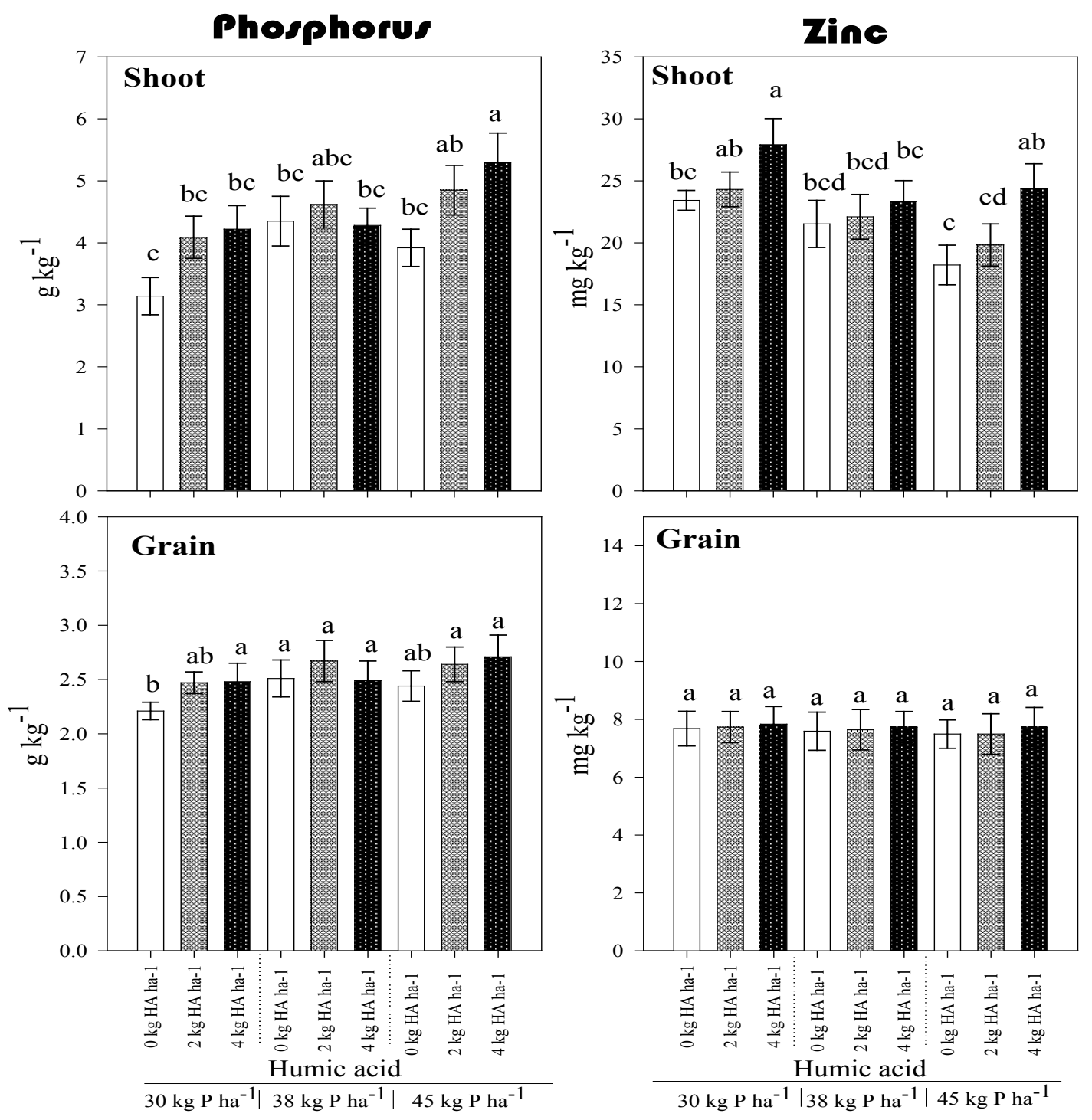

Fig. 2. $P$ and $\mathrm{Zn}$ contents in shoots and grains of maize plants grown on a calcareous soil as affected by applied $P$ and humic acid. See footnote Fig 1. Different letters indicate significant variations among treatments

TABLE 4. Grand means of $P$ and $\mathrm{Zn}$ availability in the calcareous soil as affected by the applied $P$ and humic acid

\begin{tabular}{|c|c|c|}
\hline Rate of application & Available $\mathbf{P}, \mathrm{mg} \mathrm{kg}^{-1}$ & Available $\mathrm{Zn}, \mathrm{mg} \mathrm{kg}^{-1}$ \\
\hline \multicolumn{3}{|c|}{ P- dose } \\
\hline 30.0 kg P ha-1 & $15.71 \mathrm{c}$ & $0.64 \mathrm{a}$ \\
\hline $37.5 \mathrm{~kg} \mathrm{P} \mathrm{ha}^{-1}$ & $19.63 \mathrm{~b}$ & $0.53 \mathrm{~b}$ \\
\hline $45.0 \mathrm{~kg} \mathrm{P} \mathrm{ha-1}$ & $22.63 \mathrm{a}$ & $0.42 \mathrm{c}$ \\
\hline$P$-value & $13.514 * *$ & $30.265 * *$ \\
\hline \multicolumn{3}{|c|}{ Humic acid dose } \\
\hline 0 kg HA ha ${ }^{-1}$ & $16.24 \mathrm{c}$ & $0.55 \mathrm{a}$ \\
\hline 2 kg HA ha ${ }^{-1}$ & $19.66 \mathrm{~b}$ & $0.54 \mathrm{a}$ \\
\hline 4 kg HA ha ${ }^{-1}$ & $22.06 \mathrm{a}$ & $0.50 \mathrm{a}$ \\
\hline$P$-value & $9.588 * *$ & 1.695 \\
\hline
\end{tabular}

Different letters indicate significant variations among treatments 
Amending soils with HA increased significantly $\mathrm{P}$ availability in soil. Probably, humic acid (HA) has the capability to increase P- solubility in soil (Rosa et al. 2018) through binding on calcium bridges (Baigorri et al. 2019), in addition to the formation of bioavailable phosphate nanoparticles that were stabilized by humic matter (Yang et al. 2019). In case of $\mathrm{Zn}$, the effect of humic acid seemed to be of no significant effect on $\mathrm{Zn}$ availability in soil. Two processes might take place in soil. The first one might occur through binding $\mathrm{Zn}$ ions on the carboxylic groups of HA (Ouyang et al. 2017; $\mathrm{Su}$ et al. 2019); nevertheless, HA reduced $\mathrm{Zn}$ bioavailability in soil (Rong et al. 2020). The second one is based on the stability of Zn-HA complex which is thought to be low because $\mathrm{Zn}$ is a soft metal while HA acts as a hard acid (Sparks, 2003). Thus, these complexes might set $\mathrm{Zn}$ free near the extended root hairs of the grown plants in exchange with $\mathrm{H}^{+}$ions that released by plant roots and this consequently increased significantly $\mathrm{Zn}$ uptake by the grown plants.

\section{P-partial factor productivity (PFP)}

Analysis of variance reveals that the values of phosphorus partial factor productivity PFP were affected significantly by the application of both $\mathrm{P}$-fertilizer $(\mathrm{F}=5.657, P=0.012)$ and humic $\operatorname{acid}(\mathrm{F}=5.330, P=0.015)$. In this concern, the least values of PFP were recorded for the treatments that received the highest application rate of $\mathrm{P}$-fertilizer (see Fig 4), while the highest values were recorded for application of $38 \mathrm{~kg} \mathrm{P} \mathrm{ha}^{-1}(125 \%$ of the recommended dose). On the other hand, HA raised significantly PFP in maize, especially with increasing the rate of its application, Moreover, interactions among these two factors were also of significant effect on PFP $(\mathrm{F}=4.421, P=0.012)$. In soils that received the optimum dose of $\mathrm{P}$ i.e., 30 $\mathrm{kg} \mathrm{P} \mathrm{ha}{ }^{-1}$, no significant variations were detected among PUE values owing to HA applications; however, the stimulating effect of HA was only noticeable on plants that received $\mathrm{P}$-applications higher than this dose (either 38 or $45 \mathrm{~kg} \mathrm{P} \mathrm{ha}^{-1}$ ).

\section{Conclusion}

Humic acid applications recorded positive impacts on maize productivity in calcareous soils. This amendment not only improved the partial factor productivity of P-fertilizer, but also increased $\mathrm{Zn}$ uptake by maize plants.

\section{Author Contributions}

Conceptualization, All authors; methodology, M. F. Abd El-Aziz and Ashraf M.G. Ewis; formal analysis, all authors; resources and writingoriginal draft preparation, all authors; writingreview and editing, all authors.

\section{Funding}

This research received no external funding.

\section{Conflicts of Interest}

The authors declare no conflict of interest

\section{Acknowledgement}

All authors express their deep thanks to Prof. Dr. Hassan H. Abbas (Soils and Water Department, Benha University, Egypt) for his help and valuable feedback on this manuscript.

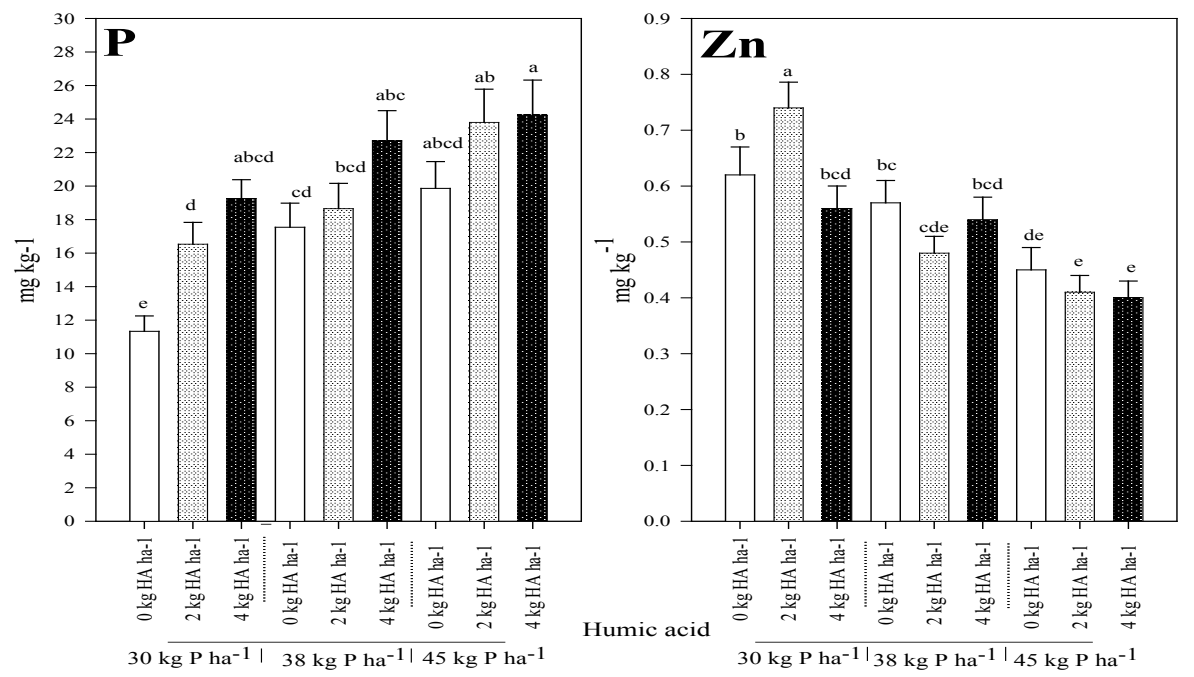

Fig. 3. $P$ and $Z n$ availability in the calcareous soil as affected by applied $P$ and humic acid. See footnote Fig. 1. Different letters indicate significant variations among treatments 

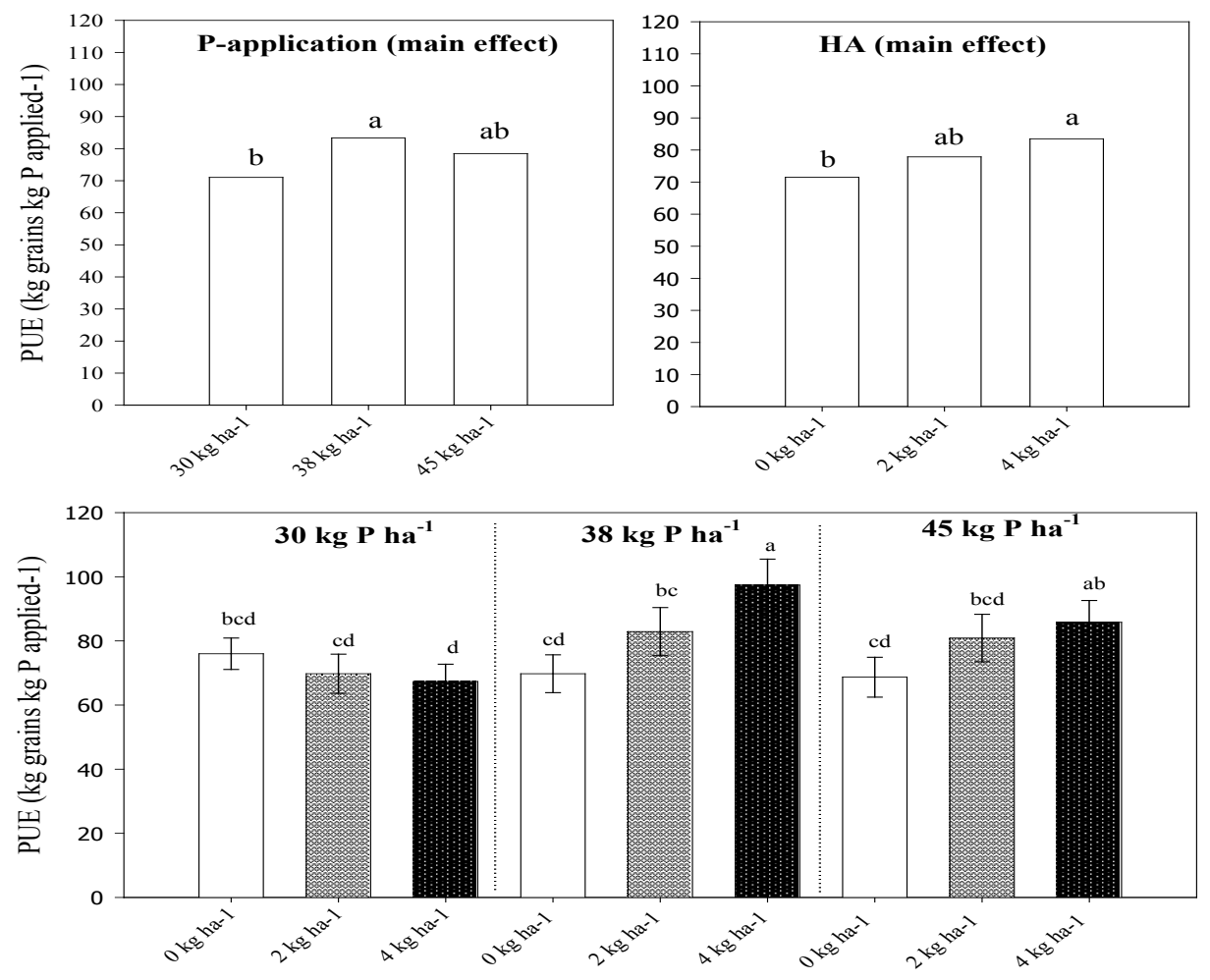

Humic acid

Fig. 4. Phosphorus partial factor productivity (PEP) of maize plants grown on a calcareous soil as affected by applied $P$ and humic acid

See footnote Fig 1. Different letters indicate significant variations among treatments

\section{References}

Abdalla, N., Ragab, M., Fári, M., El-Ramady, H., Alshaal, T., Elhawat, N., Elmahrouk, M., Elzaawely, A., Elsakhawy, T., Omara, A. and Taha, H. (2018) Nanobiotechnology for plants: Needs and risks. Env. Biodiv. Soil Security, 2, 155-174. doi: $10.21608 /$ jenvbs.2018.6711.1041

Abdelhameid, N. (2020) Effect of mycorrhizal inoculation and potassium fertilization on grain yield and nutrient uptake of sweet sorghum cultivated under water stress in calcareous soil. Egypt J Soil Sci, 60 (1), 17-29. doi: 10.21608/ ejss.2019.17512.1312

Abouhussien, E., Elbaalawy, A. and Hamad, M. (2019) Chemical properties of compost in relation to calcareous soil properties and its productivity of wheat. Egypt J Soil Sci, 59 (1), 85-97. doi: 10.21608/ejss.2019.7945.1248

Alnaimy, M.A., Soliman, K.G. and El-Naka, E.A. (2018) Evaluation of land suitability for agricultural use in El-Nubaria region, Egypt. Zagazig J. Agric. Res. 45 (6A), 2031-2048. doi: 10.21608/zjar.2018.47741
Attia, M. (2019) Status of potassium in some calcareous soils of Egypt and factors affecting its forms. Annals of Agricultural Science, Moshtohor. 57. 177-184. doi : 10.21608/assjm.2019.42247.

Baigorri, R.,Erro, J., Urrutiab, Ó., Martinez, J.M., Mandado, M., Martín-Pastor, M. and GarcíaMina, J.M. (2019)Both chemical and crystalline phase configuration influence the molecular features of humic acids in humic-calciumphosphates fertilizers. RSC $A d v_{\mathbf{2}}$ 9, 25790-25796. doi: $10.1039 / \mathrm{C} 9 \mathrm{RA} 04383 \mathrm{G}$

Bindraban, P.S., Dimkpa, C.O. and Pandey, R. (2020) Exploring phosphorus fertilizers and fertilization strategies for improved human and environmental health. BiolFertil Soils, 56, 299-317. doi:10.1007/ s00374-019-01430-2

Boguta, P. and Sokołowska, Z. (2020) Zinc Binding to fulvic acids: Assessing the impact of $\mathrm{pH}$, metal concentrations and chemical properties of fulvic acids on the mechanism and stability of formed soluble complexes. Molecules, 25, 1297. doi: 10.3390/molecules 25061297 
Cabot, C., Martos, S., Llugany, M., Gallego, B., Tolra, R. and Poschenrieder, C. (2019) A role for zinc in plant defense against pathogens and herbivores. Front. Plant Sci. 10:1171. doi:10.3389/ fpls.2019.01171

Cassman, K.G., Peng, S., Olk, D.C., Ladha, J.K., Reichardt, W., Dobermann, A. and Singh, U. (1998) Opportunities for increased nitrogen-use efficiency from improved resource management in irrigated rice systems, Field Crops Res., 56, (1-2), 7-39. doi:10.1016/S0378-4290(97)00140-8.

Cieschi, M. T., Polyakov, A. Y., Lebedev, V. A., Volkov, D.S., Pankratov, D. A., Veligzhanin, A. A., Perminova, I. V. and Lucena, J.J. (2019) Ecofriendly iron-humicNnanofertilizers synthesis for the prevention of iron chlorosis in soybean (Glycine max) grown in calcareous soil. Front Plant Sci., 10, 413. doi: $10.3389 /$ fpls. 2019.00413

Delgado, A., Madrid, A., Kassem, S., Andreu, L. and Del Campillo, M.D.C. (2002) Phosphorus fertilizer recovery from calcareous soils amended with humic and fulvic acids. Plant Soil, 245, 277-286. doi:10.1023/A:1020445710584

Dhaliwal, S.S., Naresh, R.K., Mandal, A., Singh, R. and Dhaliwal, M.K. (2019) Dynamics and transformations of micronutrients in agricultural soils as influenced by organic matter build-up: A review. Environmental and Sustainability Indicators, 1-2, 100007. doi $: 10.1016 / j$. indic.2019.100007.

Durand, N., Monger, H.C., Canti, M.G., and Verrecchia, E.P. (2018) Chapter 9 - Calcium Carbonate Features, Editor(s): Georges Stoops, Vera Marcelino, FloriasMees, Interpretation of Micromorphological Features of Soils and Regoliths (Second edition), Elsevier, pp 205-258, doi:10.1016/B978-0-44463522-8.00009-7.

El-Ghamry, A., Mosa, A., Alshaal, T. and El-Ramady, H. (2018) Nanofertilizers vs. biofertilizers: New insights. Env. Biodiv. Soil Security, 2, 51-72. doi: 10.21608/jenvbs.2018.3880.1029

El-Naqma, K. (2020) The role of humate substances in controlling synergism and antagonism of nutrients uptake by potato plants. Env. Biodiv. Soil Security, 4, 149-165. doi: 10.21608/jenvbs.2020.29796.1096

El-Ramady, H., Olle, M., Eichler-Löbermann, B. and Schnug, E. (2020) Towards a new concept of sustainable plant nutrition. Env. Biodiv. Soil Security, 4, 1-6. doi: 10.21608/ jenvbs.2020.21970.1080
Elser, J. and Bennett, E. (2011) A broken biogeochemical cycle. Nature, 478, 29-31. doi:10.1038/478029a

Engels, C., Kirkby, E. and White, P. (2012) Mineral Nutrition, Yield and Source-Sink Relationships. Mineral Nutrition, Yield and Source-Sink Relationships. In: Marschner's Mineral Nutrition of Higher Plants (Marschner, P. ed), Third Edition, Elsevier, Amsterdam, pp: 85-134. doi: 10.1016/ B978-0-12-384905-2.00006-6

Farid, I., Abbas, M. and A. El-Ghozoli (2018) Implications of humic, fulvic and K-humate extracted from each of compost and biogas manures as well as their teas on faba bean plants grown on a TypicTorripsamment soil and emissions of soil $\mathrm{CO}_{2}$. Egypt J Soil Sci, 58 (3), 275-289. doi: 10.21608/ejss.2018.3386.1168

Freitas, E.V. and Nascimento, C. (2017) Degradability of natural and synthetic chelating agents applied to a lead-contaminated soil. J Soils Sediments, 17, 1272-1278. doi: 10.1007/s11368015-1350-9

Gao, W., Blaser, S.R.G.A., Schlüter, S. and Shen, J. (2019) Effect of localised phosphorus application on root growth and soil nutrient dynamics in situ - comparison of maize (Zea mays) and faba bean (Viciafaba) at the seedling stage. Plant Soil, 441, 469-483. doi:10.1007/s11104-019-04138-2

Hawkesford, M., Horst, W., Kichey, T., Lambers, H., Schjoerring, J., Møllerm I.S., and White, P. (2012) Functions of micronutrients, In Marschner's Mineral Nutrition of Higher Plants. (Marschner, P. ed), Third Edition, Elsevier, Amsterdam, pp 135 189. doi: 10.1016/B978-0-12-384905-2.00006-6

Horuz, A. (2020) Effects of humic acids from different sources on sodium and micronutrient levels in corn plants. SainsMalaysiana, 49 (7): 1533-1542. doi: 10.17576/jsm-2020-4907-06

IzharShafi, M., Adnan, M., Fahad, S., Wahid, F., Khan, A., Yue, Z., Danish, S., Zafar-ul-Hye, M., Brtnicky, M. and Datta, R. (2020) Application of single superphosphate with humic acid improves the growth, yield and phosphorus uptake of wheat (Triticum aestivum L.) in calcareous soil. Agronomy, 10, 1224. doi:10.3390/agronomy 10091224

Jones, C.A., Jacobsen, J.S. and Mugaas, A. (2007) Effect of low-rate commercial humic acid on phosphorus availability, micronutrient uptake, and spring wheat yield. Comm. Soil Sci. Plant Anal., 38: 7-8, 921933. doi: 10.1080/00103620701277817 
Karimi, A., Moezzi, A., Chorom, M. and Enayatizamir, N. (2020) Application of biochar changed the status of nutrients and biological activity in a calcareous soil. J. Soil Sci Plant Nutr. 20, 450-459. doi: 10.1007/s42729-019-00129-5

Klute, A. (1986) Part 1. Physical And Mineralogical Methods. ASA-SSSA-Agronomy, Madison, Wisconsin USA.

Leventoglu, H. and Erdal, i.(2014) Effect of high humic substance levels on growth and nutrient concentration of corn under calcareous conditions, Journal of Plant Nutrition, 37:12,2074-2084,doi: 10.1080/01904167.2014.920373

Leytem, A.B., Dungan, R.S. and Moore, A. (2011) Nutrient availability to corn from dairy manures and fertilizer in a calcareous soil, Soil Sci. 176 (8), 426-434. doi: 10.1097/SS.0b013e31822391a6

Lindsay, W.L. (1979) Chemical Equilibria In Soil. John Wiley \& Sons, New York.López-Rayo, S., Sanchis-Pérez, I., Ferreira, C.M.H. and J.J. Lucena (2019) [S,S]-EDDS/Fe: A new chelate for the environmentally sustainable correction of iron chlorosis in calcareous soil, Sci Total Environ. 647, 1508-1517. doi: 10.1016/j.scitotenv.2018.08.021.

Maruf, M.T. and Rasul, G. (2019) Influence of humic acid and sulfur on the bioavailability of some micronutrients in calcareous soils. Plant Arch. 19, 1785-1794.

Morsy, A.M., Salem, M.A. and Elmamlouk, H.H. (2019) Evaluation of dynamic properties of calcareous sands in Egypt at small and medium shear strain ranges, Soil Dyn Earthq Eng, 116, 692708, doi:10.1016/j.soildyn.2018.09.030.

Nikbakht, A., Kafi, M., Babalar, M., Xia, Y.P., Luo, A. and Etemadi, N. (2008) Effect of humic acid on plant growth, nutrient uptake, and postharvest life of Gerbera, J. Plant Nutr. 31:12, 21552167-. doi: $10.1080 / 01904160802462819$

Noulas, C., Tziouvalekas, M. and Karyotis, T. (2018) Zinc in soils, water and food crops, Journal of Trace Elements in Medicine and Biology, 49, 252260, doi:10.1016/j.jtemb.2018.02.009.

Olmos, S., Esteban, E. and Lucena, J.J. (1998) Micronutrient extraction in calcareous soils treated with humic concentrates, J. Plant Nutr. 21 (4),687697. doi: $10.1080 / 01904169809365435$

Omara, A., Elsakhawy, T., Alshaal, T., El-Ramady, H., Kovács, Z. and Fári, M. (2019) Nanoparticles: A novel approach for sustainable agroproductivity. Env. Biodiv. Soil Security, 3, 29-62. doi: $10.21608 /$ jenvbs.2019.7478.1050

Ouyang, K., Yu, X.-Y., Zhu, Y., Gao, C., Huang, Q. and Cai, P. (2017) Effects of humic acid on the interactions between zinc oxide nanoparticles and bacterial biofilms, Environ. Pollut. 231, 11041111, doi:10.1016/j.envpol.2017.07.003.

Raghothama, K.G. (2005) Phosphorus and Plant Nutrition: An Overview. In Phosphorus: Agriculture and the Environment (Eds: J. Thomas Sims, A.N. Sharpley and M.L. Cabrera), Agronomy Monographs, 46.,doi:10.2134/agronmonogr46.c11

Rajaie, M. and Tavakoly, A.R. (2018) Iron and/or acid foliar spray versus soil application of Fe-EDDHA for prevention of iron deficiency in Valencia orange grown on a calcareous soil. J.Plant Nutr. 41 (2), 150158. doi: $10.1080 / 01904167.2017 .1382523$

Ranum,P., PeDa-Rosas, J.P. and Garcia-Casal, M.N. (2014) Global maize production, utilization, and consumption. Ann. N.Y. Acad. Sci. 1312, 105-112. doi: $10.1111 /$ nyas. 12396

Rong, Q., Zhong, K., Huang, H., Li, C., Zhang, C. and Nong, X. (2020) Humic acid reduces the available cadmium, copper, lead, and zinc in soil and their uptake by tobacco. Appl. Sci. 10, 1077. doi: $10.3390 /$ app 10031077

Rosa, S.D., Silva, C.A. and Maluf, H.J.G.M. (2018) Wheat nutrition and growth as affected by humic acid-phosphate interaction. J. Plant Nutr. Soil Sci., 181: 870-877. doi:10.1002/jpln.201700532

Sahrawat, K.L., G.R. Kumar and J. K. and Rao,J.K. (2002) Evaluation of triacid and dry ashing procedures for determining potassium, calcium, magnesium, iron, zinc, manganese, and copper in plant materials. Comm. Soil Sci. Plant Anal. 33 (12), 95-102. doi: $10.1081 /$ CSS- 120002380

Saritha, A., Ramanjaneyulu, A.V., Sainath, N. and Umarani, E.(2020) Nutritional importance and value addition in maize. Biotica Research Today, 2 (9), 974-977.

Shams, A. and Abbas, M.H.H. (2019) Can hydroxyapatite and boron oxide nano-fertilizers substitute calcium superphosphate and boric acid for broccoli (Brassica oleracea var. italica) Grown on A Heavy Clay Soil? Egyptian Journal of Horticulture, 46 (2), 215-234. doi: 10.21608/ ejoh.2019.16154.1113

Sims, J.T. and Pierzynski, G.M. (2005) Chemistry of Phosphorus in Soils. In: Chemical Processes in Soisl (Tabatabai, M.A., Sparks, D.L., Eds.), 
Soil Science Society of America Book Series, 8, Madison, 151-192

Soltanpour, P.N. (1985) Use of ammonium bicarbonate DTPA soil test to evaluate elemental availability and toxicity. Commun Soil Sci Plant Anal. 16, 323338.doi:10.1080/00103628509367607

Sparks, D.L. (2003) Environmental Soil Chemistry, $2^{\text {nd }}$ ed., Academic Press, Amesterdam

Sparks, D.L., Page, A.L., Helmke, P.A., Loeppert, R.H., Soltanpour, P.N., Tabatabai, M.A., Johnston, C.T. and Sumner, M.E. (1996) Methods of Soil Analysis Part 3-Chemical Methods, 5.3. SSSA Book Series, Madison, WI.

Su S., Huang Y., Han G., Guo Z. and Liu, F. (2019) Study of the Adsorption of Humic Acid with $\mathrm{Zn}^{2+}$ by Molecular Dynamic Simulation and Adsorption Experiments. In: Li B. et al. (Eds) Characterization of Minerals, Metals, and Materials. The Minerals, Metals \& Materials Series. Springer, Cham, pp 3341-. doi: 10.1007/978-3-030-05749-7 4

Umair Hassan, M., Aamer, M., UmerChattha, M., Haiying, T., Shahzad, B., Barbanti, L., Nawaz, M., Rasheed, A., Afzal, A., Liu, Y. and Guoqin, H. (2020) The critical role of zinc in plants facing the drought stress. Agriculture , 10, 396. doi: 10.3390/ agriculture 10090396

Virto, I., Antón, R., Apesteguía, M. and Plante, A. (2018) Chapter 9 - Role of Carbonates in the Physical Stabilization of Soil Organic Matter in Agricultural Mediterranean Soils, Editor(s): María Ángeles Muñoz, Raúl Zornoza, Soil Management and Climate Change, Academic Press, pp. 121136. doi: 10.1016/B978-0-12-812128-3.00009-4.

Wang, S., Wang, Z., Gao, Y., Liu, L., Yu, R., Jin, J., Luo, L., Hui, X., Li, F. and Li, M. (2017) EDTA alone enhanced soil zinc availability and winter wheat grain $\mathrm{Zn}$ concentration on calcareous soil. Environ Exp Bot, 141, 19-27. doi: 10.1016/j. envexpbot.2017.06.008.

Wang, X., Gao, Y., Hu, B. and Chu, G.(2019) Comparison of the hydrolysis characteristics of three polyphosphates and their effects on soil phosphrous and micronutrient availability. Soil Use Manage. 35: 664-674. doi: 10.1111/sum. 12526

Yadav, R.L., Dwivedi, B.S. and Pandey, P.S. (2000) Rice-wheat cropping system: assessment of sustainability under green manuring and chemical fertilizer inputs, Field Crops Res. 65 (1), 15-30. doi:10.1016/S0378-4290 (99)00066-0.

Yang, F., Zhang, S., Song, J., Du, Q., Li, G. Tarakina, N.V. and Antonietti, M. (2019) Synthetic humic acids solubilize otherwise insoluble phosphates to improve soil fertility, Antonietti Angew. Chem. Int. Ed. 58, 18813-18816. doi: 10.1002/ anie. 201911060

Zhang, Y., Deng, Y., Chen, R., Cui, Z.-L., Chen, X.P., Yost, R., Zhang, F.-S. and Zou, C.-Q. (2012) The reduction in zinc concentration of wheat grain upon increased phosphorus-fertilization and its mitigation by foliar zinc application. Plant Soil, 361, 143-152. doi: 10.1007/s11104-012-1238-z

Zhu, Y.-G., Smith, S.E. and Smith, F.A. (2001) Zinc $(\mathrm{Zn})$-phosphorus $(\mathrm{P})$ interactions in two cultivars of spring wheat (Triticum aestivum $\mathrm{L}$.) differing in $\mathrm{P}$ uptake efficiency, Annals of Botany, 88 (5), 941945, doi: 10.1006/anbo.2001.1522.

Zulfiqar, F., Navarro, M., Ashraf, M., Akram, N.A. and Munné-Bosch, S. (2019) Nanofertilizer use for sustainable agriculture: Advantages and limitations, Plant Science, 289, 110270, doi: 10.1016/j.plantsci.2019.110270. 